\title{
Ensaio Visual - Um ateliê dentro da pesquisa.
}

\author{
Camila Serino Lia (UNESP)
}

\begin{abstract}
RESUMO
Nessas imagens, narro trecho do meu percurso de pesquisa de doutorado, iniciada em 2017 no PPG IA UNESP ela busca investigar concepções e práticas do campo da mediação cultural em museus e instituições culturais como oficinas, ateliês e outras proposições artísticas concebidas por arte/educadores para diversos públicos. Os meus referenciais teóricos e metodológicos vêm sendo compreendidos na convergência e hibridização com experiências artísticas pessoais, materializadas por meio de desenhos, fotografias e registros em cadernos de campo que ajudam a compor os trabalhos das disciplinas obrigatórias cursadas. Com base em John Dewey, entre outros teóricos, construo uma pesquisa que em si mesma seja experiência artística e estética. Quem sabe, é possível assim, imaginar um ateliê dentro da própria pesquisa, como espaço de pensamento, criação e conhecimento.
\end{abstract}

PALAVRAS-CHAVE: Arte/educação; mediação cultural; experiência estética.

\section{RESUMEN}

En estas imágenes, narro trecho del recorrido de investigación de doctorado, iniciada en 2017 en el PPG IA UNESP ella busca investigar concepciones y prácticas del campo de la mediación cultural en museos e instituciones culturales como talleres y otras proposiciones artísticas concebidas por arte / educadores para diversos públicos. Mis referenciales teóricos y metodológicos vienen siendo comprendidos en la convergencia e hibridización con experiencias artísticas personales, materializadas por medio de dibujos, fotografías y registros en cuadernos de campo que ayudan a componer los trabajos de las disciplinas obligatorias cursadas. Con base en John Dewey, entre otros teóricos, construyo una investigación que en sí misma sea experiencia artística y estética. Quien sabe, es posible así, imaginar un taller dentro de mi propia investigación, como espacio de pensamiento, creación y conocimiento.

PALABRAS CLAVE: Arte / educación; mediación cultural; experiencia estética. 


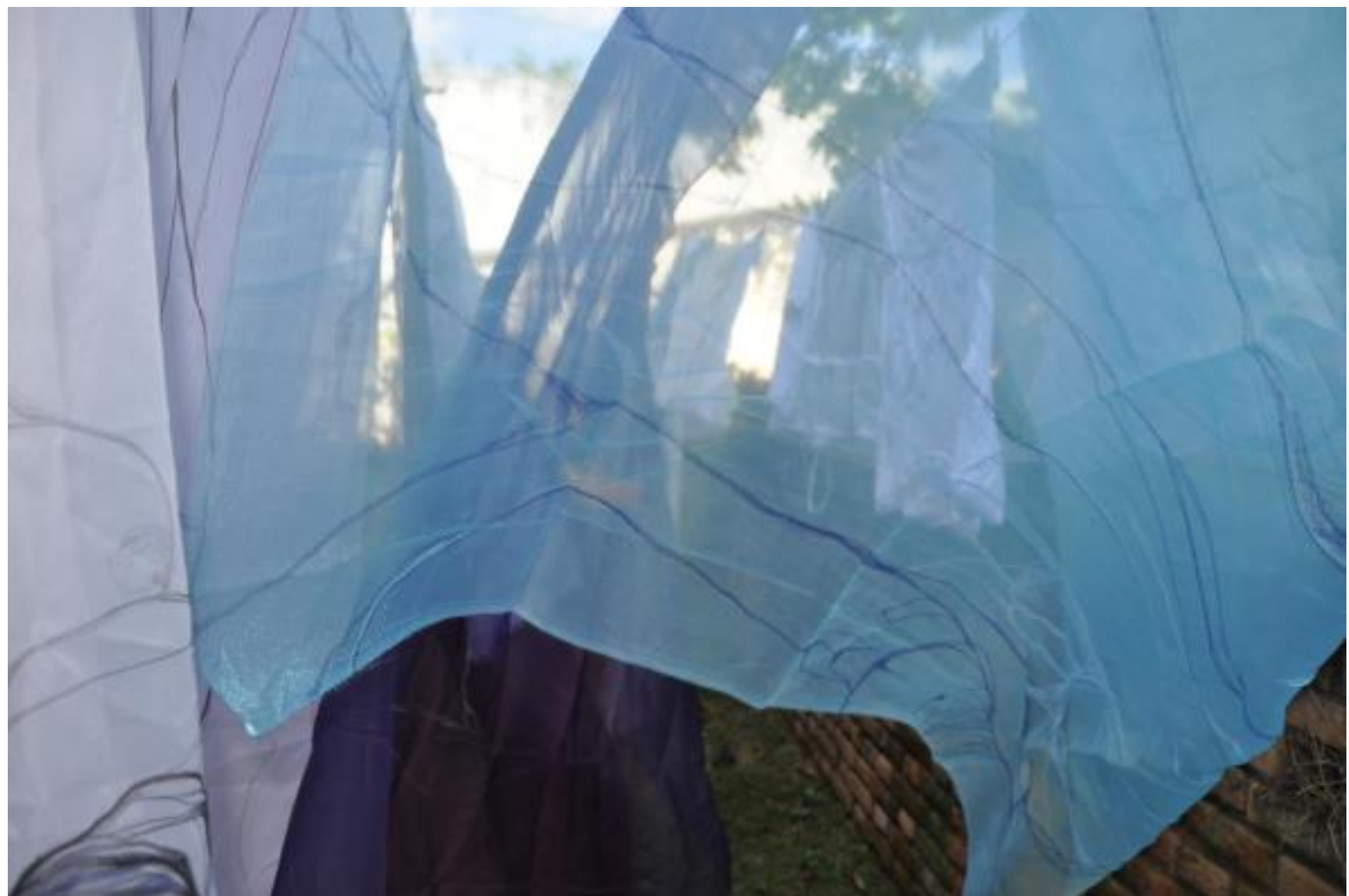

Imagem 1: Série Cartografias: corpos e desenhos no varal de casa. 2017

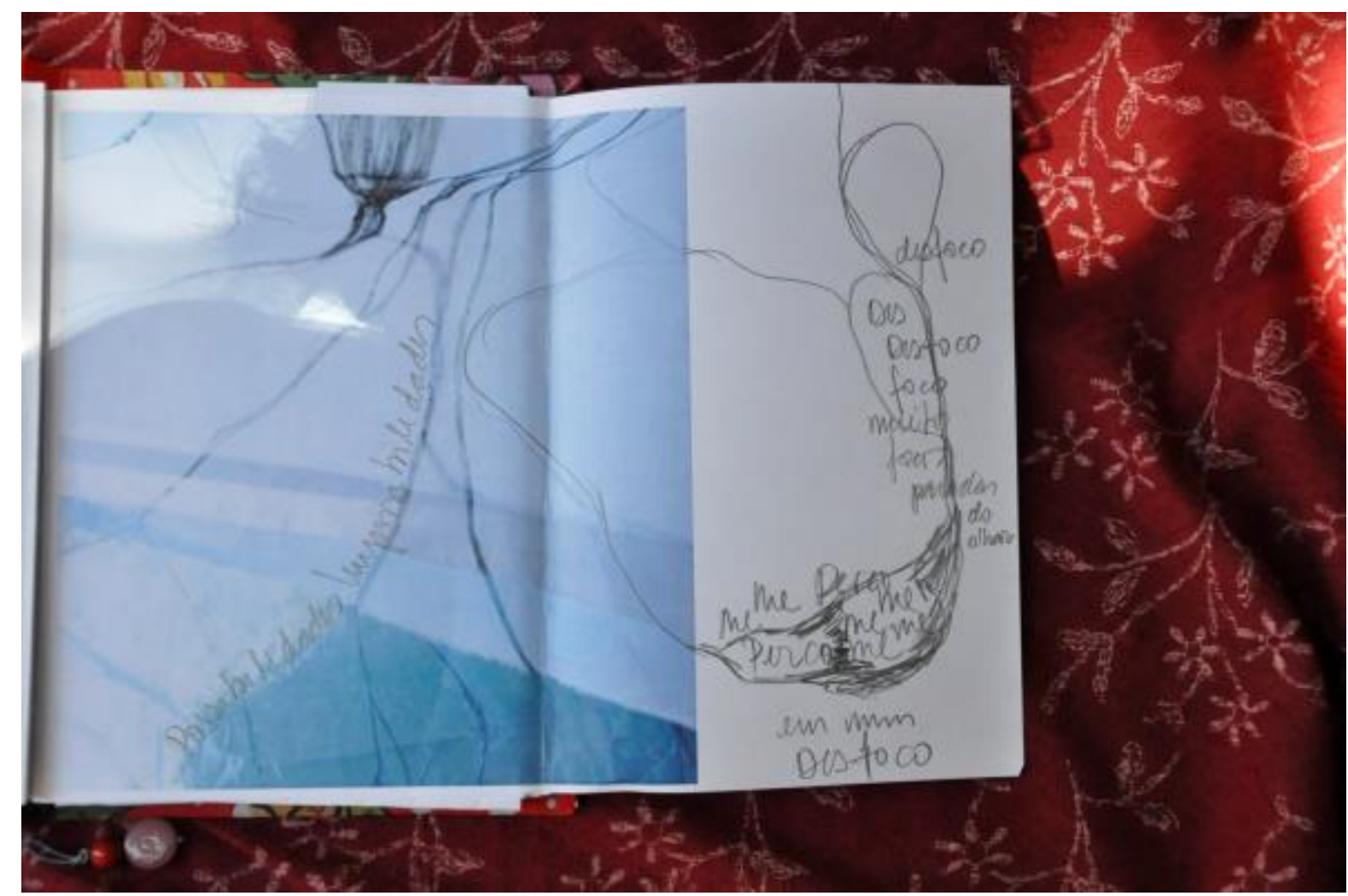

Imagem 2. Série Cartografias de si: escrever, desenhar e pesquisar. 2017 


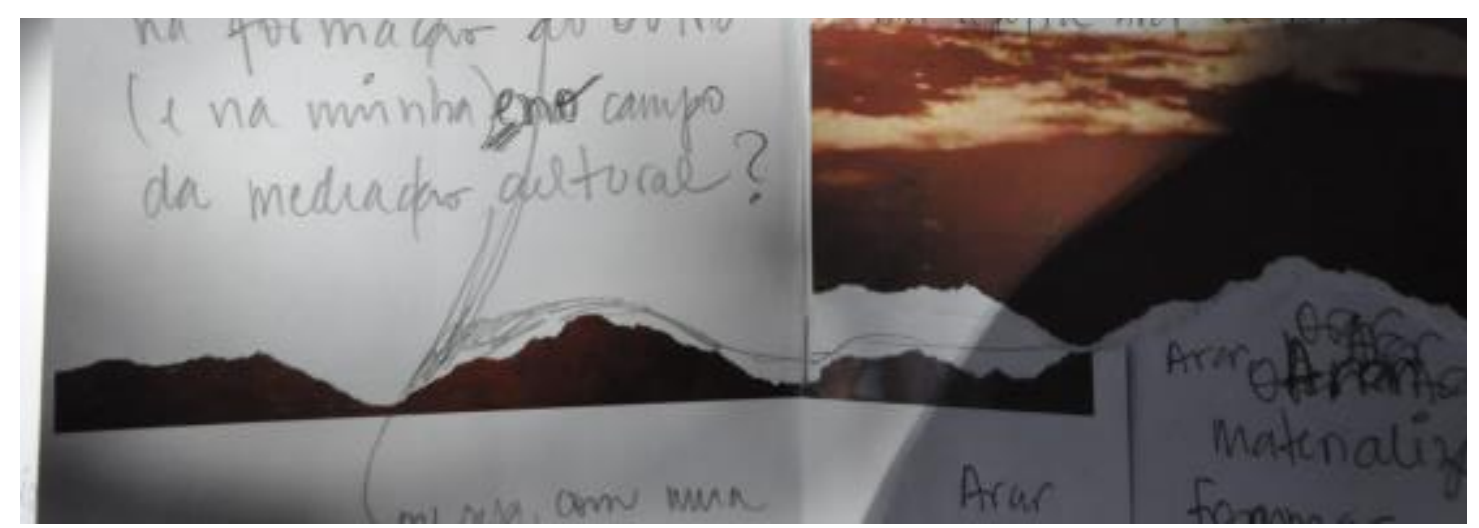

Imagem 3. Série Cartografias de si: escrever, desenhar e pesquisar. 2017

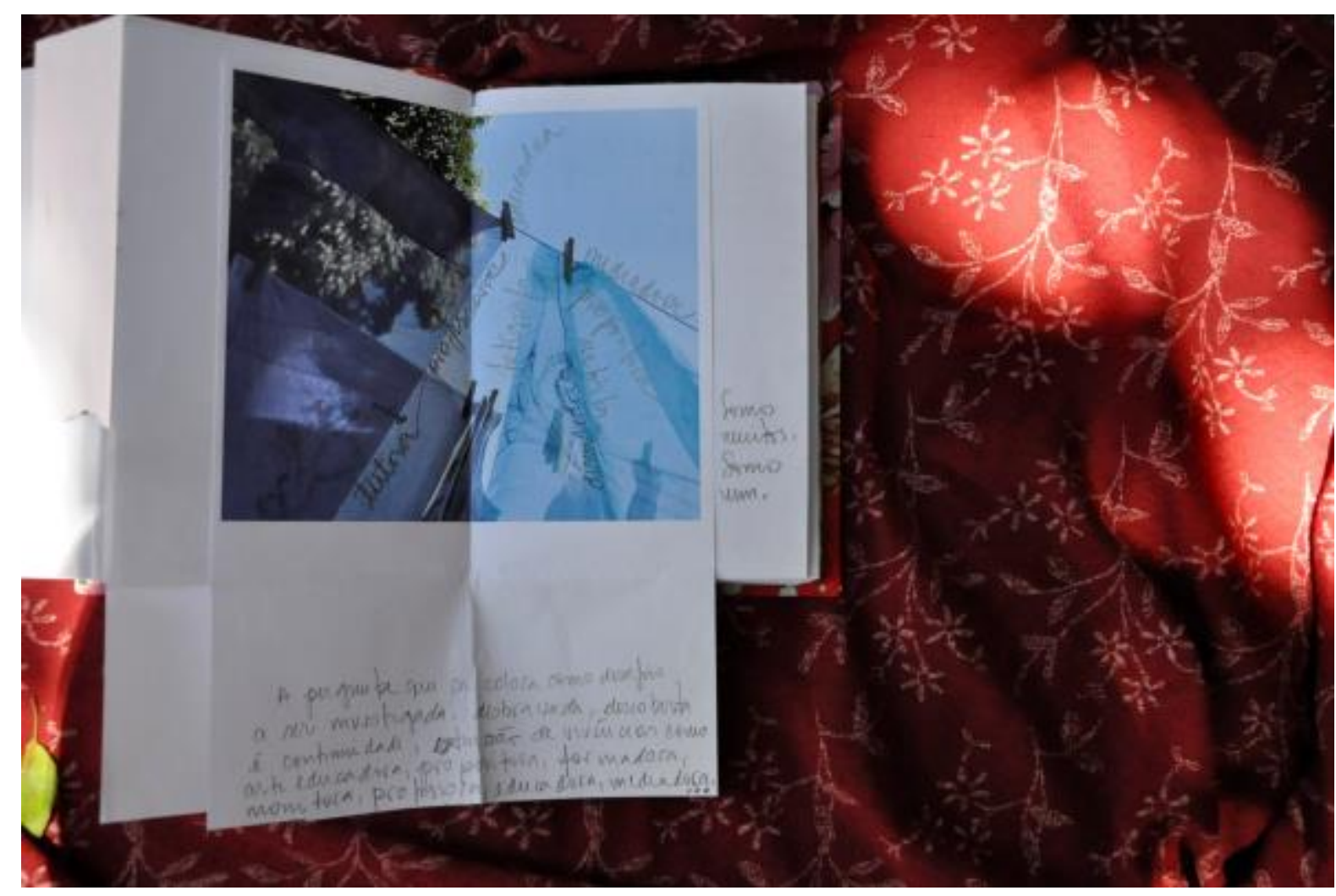

Imagem 4. Série Cartografias de si: escrever, desenhar e pesquisar. 2017 


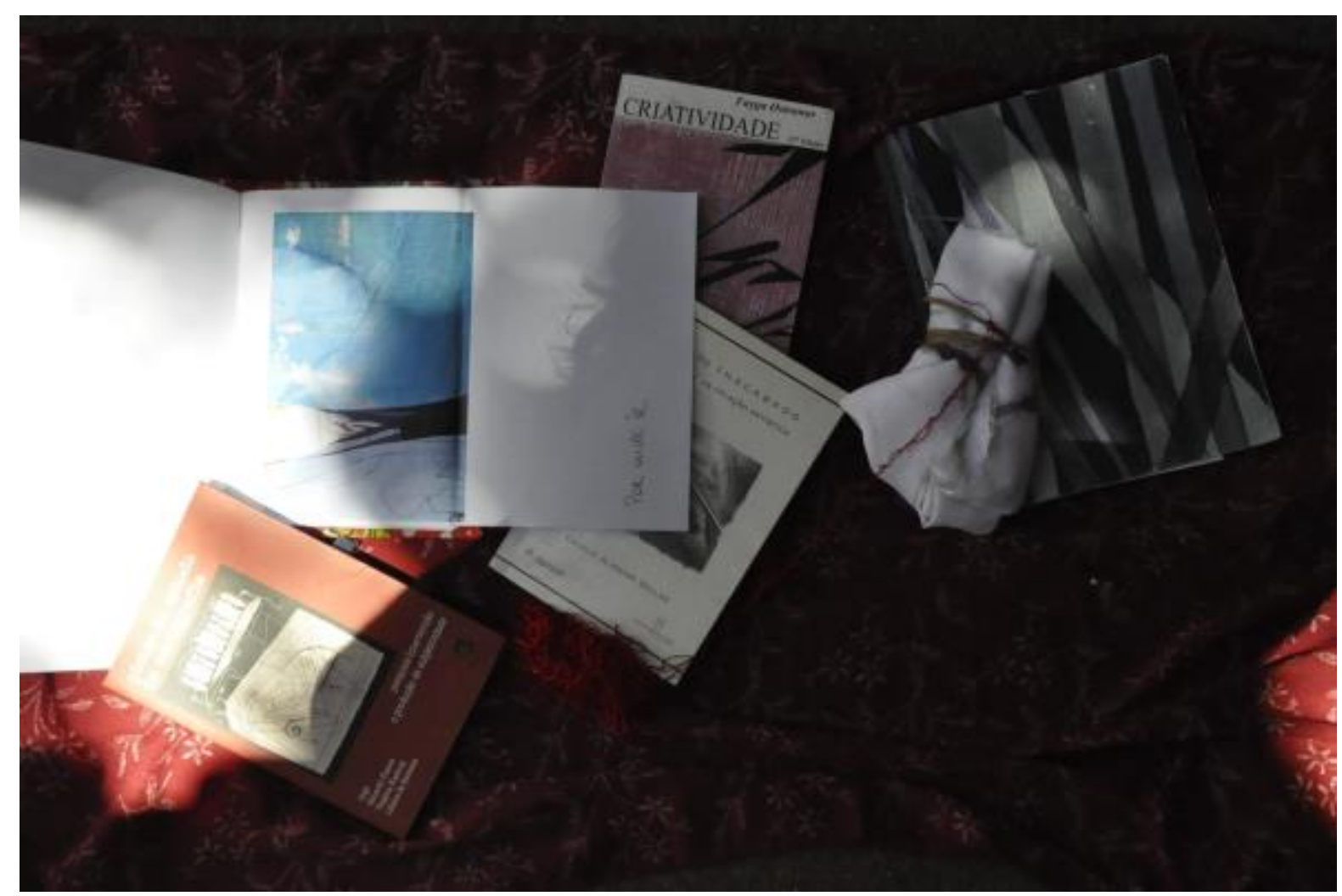

Imagem 5. Série Cartografias de si: escrever, desenhar e pesquisar. 2017

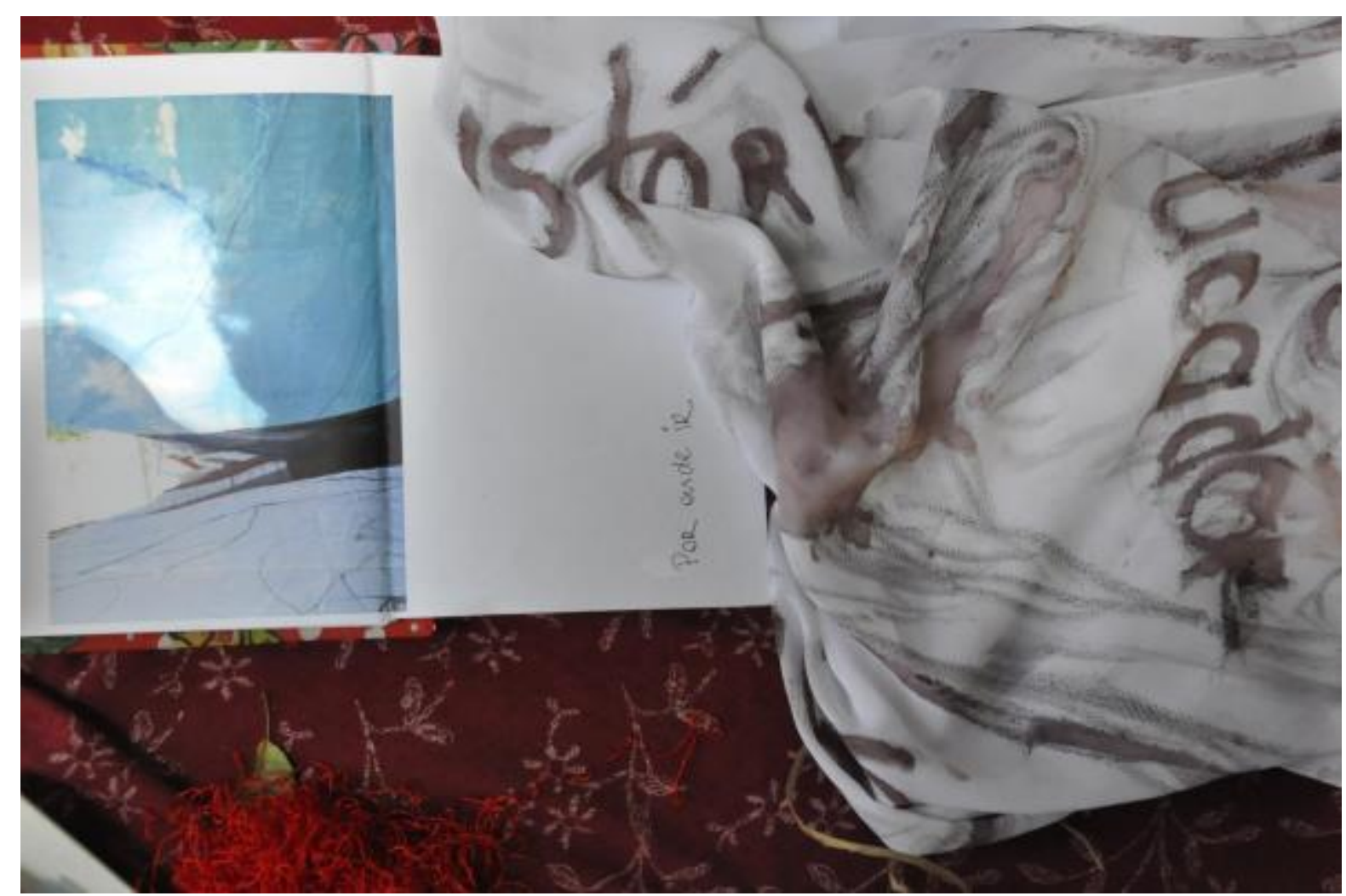

Imagem 6. Série Cartografias de si: escrever, desenhar e pesquisar. 2017 


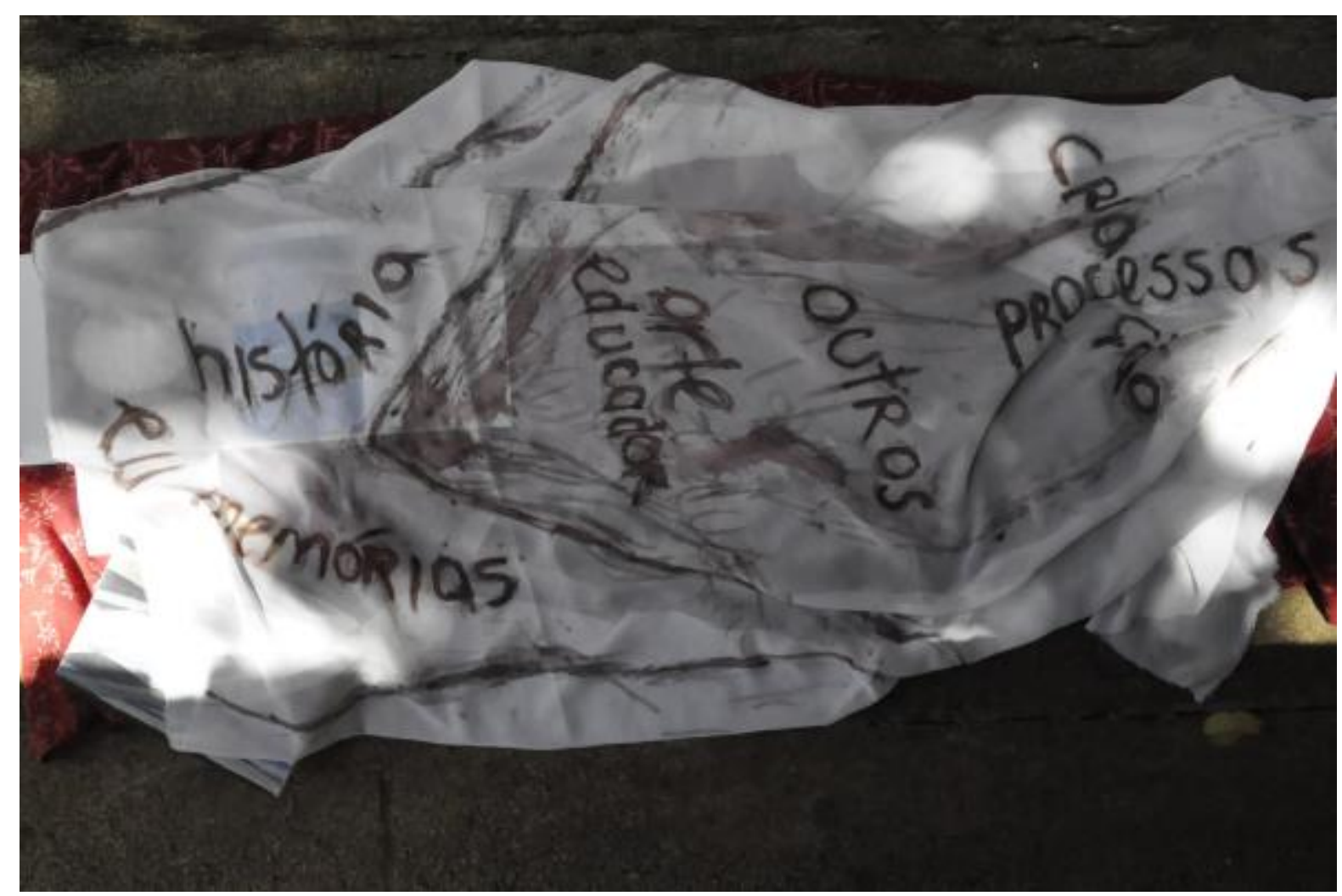

Imagem 7. Série Cartografias de si: escrever, desenhar e pesquisar. 2017

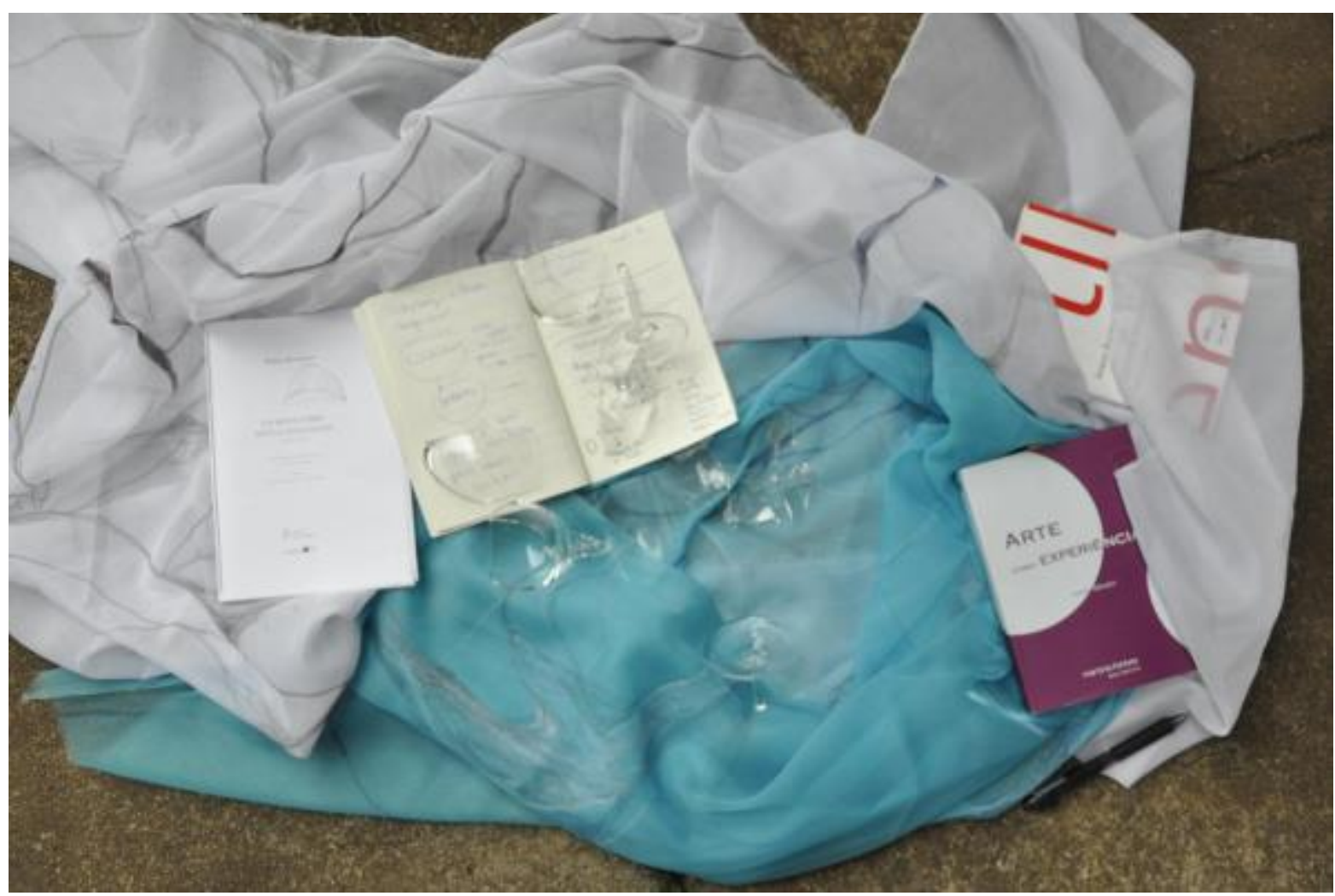

Imagem 8. Série Imagens vigilantes: fotografar e pesquisar. 2018. 


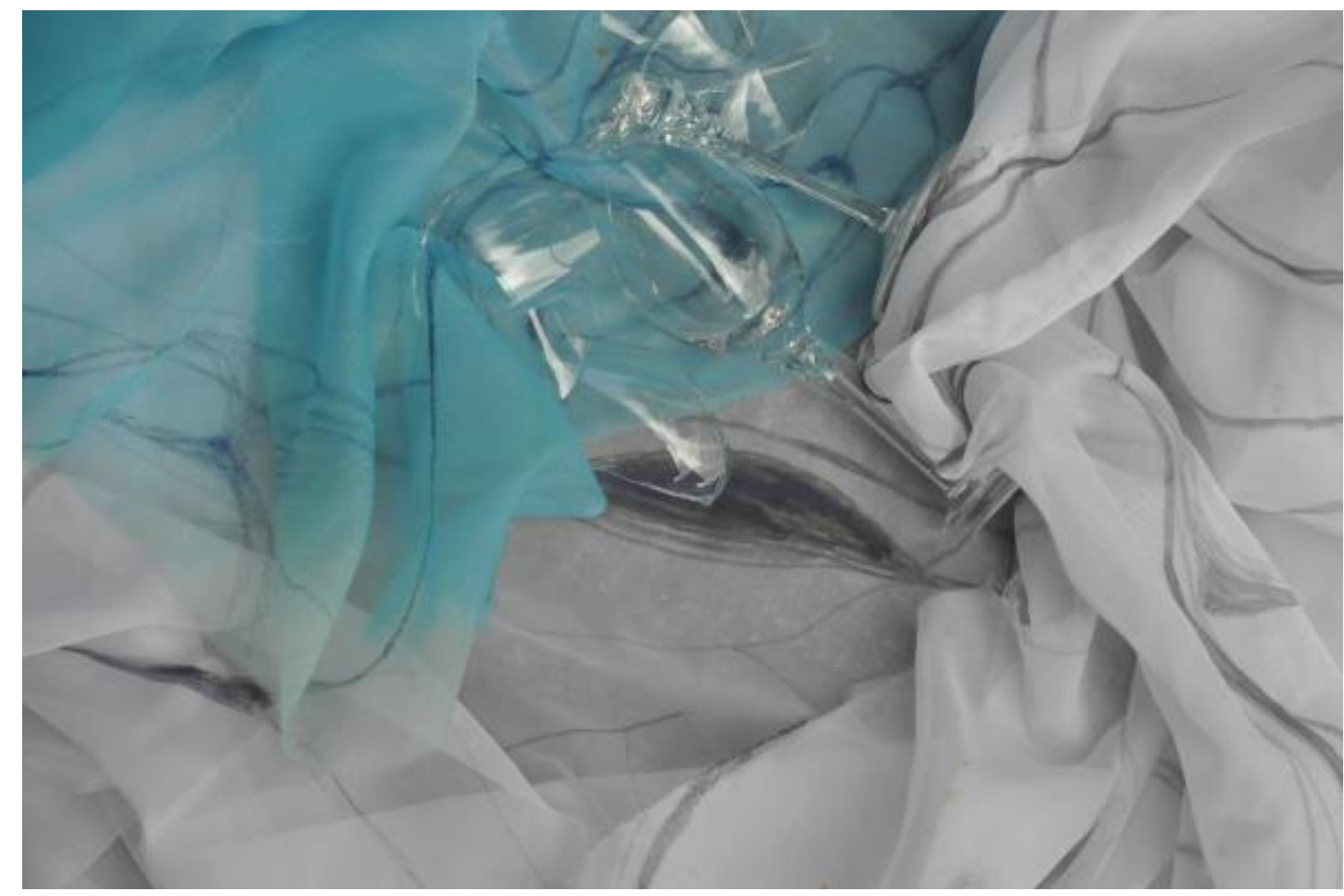

Imagem 9. Série Imagens vigilantes: fotografar e pesquisar. 2018.

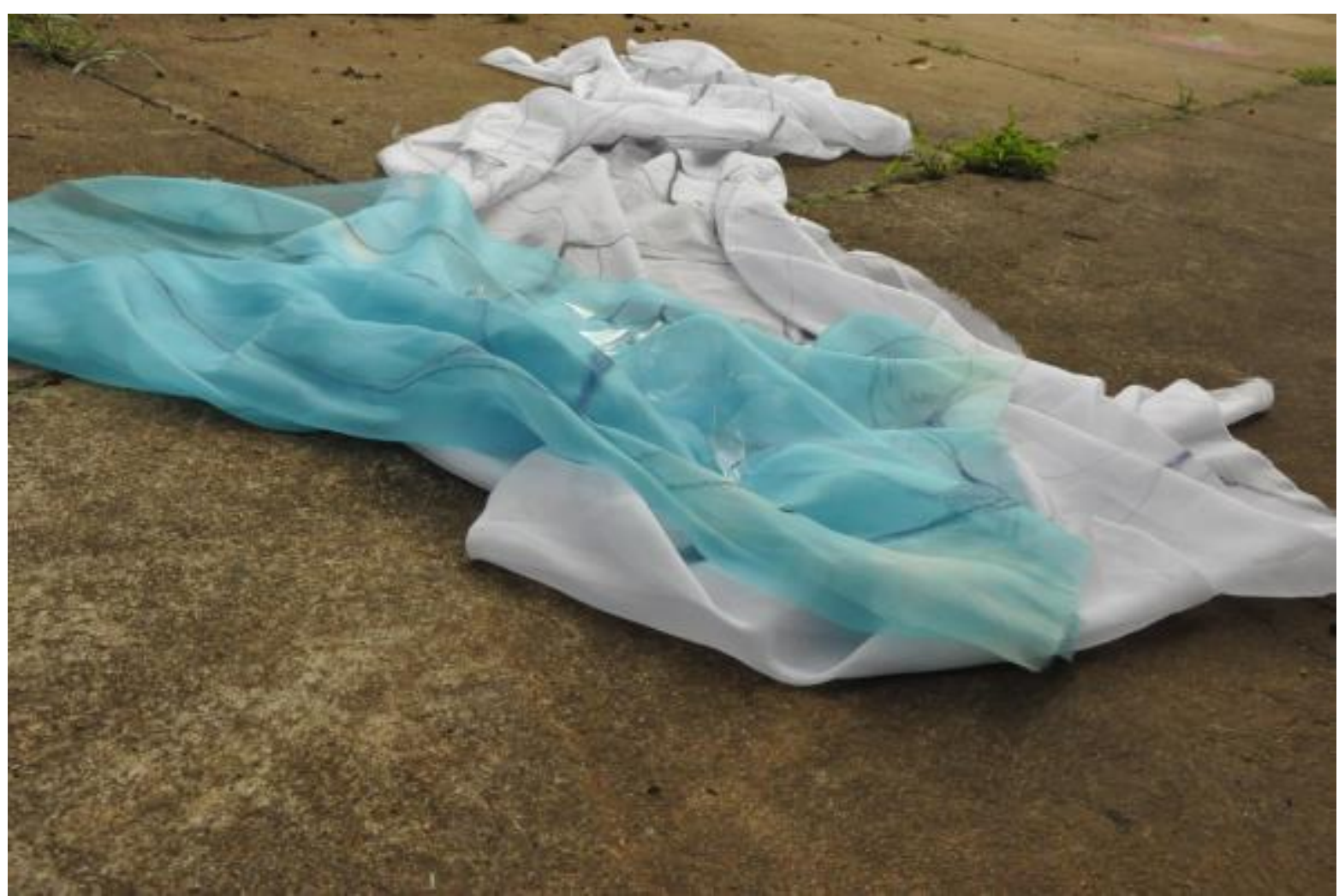

Imagem 10. Série Imagens vigilantes: fotografar e pesquisar. 2018. 


\section{Referências}

BENJAMIN, Walter. A tarefa do Tradutor In Gagnebin, J. M. (Org.). Escritos sobre mito e linguagem. Trad. Susana Kampff Lages. São Paulo: Ed. 34, 2011

DEWEY, John. Arte como experiência. Trad. Vera Ribeiro. São Paulo: Martins Fontes, 2010 .

MARESCA, Sylvain. o silêncio das Imagens In SAMAIN, Etienne(Org.) Como pensam as Imagens. $1^{a}$. reimp. Campinas: Ed. Unicamp, 2014, pp. 37-40.

OSTROWER, Fayga. Criatividade e processos de criação. 27. ed. Petropólis: Vozes, 2012.

PASSOS,Eduardo; KASTRUP, Virgínia; ESCÓSSIA, Liliana da. Pistas do método da cartografia: pesquisa-intervenção e produção de subjetividade. Porto Alegre: Sulina, 2015.

RANCIÈRE, Jaques. A partilha do sensível: estética e política. Trad. Mônica Costa Netto. São Paulo: Editora 34, 2009.

SALLES, Cecília de Almeida. Gesto inacabado: processo de criação artística. São Paulo: FAPESP, Annablume, 1998.

\section{Camila Serino Lia}

http: / / lattes.cnpq.br/0724269674252914

Doutoranda em Arte Educação, na linha de pesquisa Processos artísticos, experiências educacionais e mediação cultural, sob orientação da Prof ${ }^{a}$ Dra $^{a}$ Rejane Galvão Coutinho. Bolsista CAPES. 